seemed to concentrate and also on the limitation of the Bill to the defence services. Sir Frank Soskice, and also other Opposition speakers, while concerned at the implications for industry of the Bill as regards the supply of defence materials to allied countries, ignored the assurance of the Howitt Committee on this point. On the other hand, he sought to extend the scope of the Bill to cover contracts for other services of the Crown, especially the health services. The trend of his remarks regarding the disclosure of technical information are indeed disturbing. It would be most unfortunate if industry came to rely excessively upon secrecy rather than upon patents, even if the patent law were more unsuited to the needs of British industry to-day than appears to be the case.

In a recent article on this subject in the Journal of Industrial Economics $(5,157 ; 1957)$, Mr. C. A. Bloxam expressed the opinion that the patent system is the only one so far devised which reconciles the encouragement of technological innovation by commercial interests with encouragement to make avail able to the public the maximum amount of informa. tion regarding such innovations. Mr. Bloxam's inquiry has satisfied him that it also offers effective safeguards to prevent the use of patents for suppressing inventions ; indeed, a particularly interesting part of Mr. Bloxam's article is that in which he presents reasons for believing that patents are not suitable instruments for suppressing invention. The article is worth noting in this connexion as setting the issues raised by the Bill in the context of those which determine the rate of application of science and technology in industry, particularly in view of the comparatively sterile debate referred to ; the latter makes desirable a more objective discussion such as is to be found in the report on industry and technical progress prepared for the Science and Industry Committee of the Royal Society of Arts, the British Association and the Nuffield Foundation.

Sir Frank Soskice did not suggest that information should be disclosed to rivals, but he appeared to take a remarkably optimistic view as to the safety of information disclosed to Government departments, an optimism that is unlikely to be shared by the overseas manufacturer whom the Howitt Committee rightly had in mind. There is a question of confidence here which is particularly important if British industry is to take the fullest advantage of the opportunities for development to which $\mathrm{Mr}$. J. H. Dunning has directed attention. Furthermore, this question of technical information is particularly important in regard to research and development in pharmaceuticals, which would appear to be one aspect of the health services that Sir Frank Soskice had in mind.

Mr. W. R. Rees-Davies, in supporting the Bill, was much more practical. He recognized that it might be necessary to widen the powers of the Bill later ; but he held that the experience gained under the present Bill would give a much clearer idea of the practical difficulties and how best to handle the question of private contracts. Sir David Eccles, in replying on the debate, was emphatic that at present overseas manufacturers would be unwilling to enter into agreements involving the supply of technical information to British firms, if the Government possessed the wider powers which the Opposition sought to write into the Bill.

The problem is undoubtedly difficult, and the debate failed to give weight to some of the factors to which the Howitt Committee directed attention. It is, in fact, intimately related to the vital question of Anglo-American co-operation. Britain benefits greatly, as the Howitt Committee observed, throughout the whole economy, from the use of the knowledge developed particularly in the United States; and currency difficulties, geographical propinquity and sentimental ties all lead Commonwealth and Western European countries to turn more readily to the United Kingdom than to the United States. Anything which checked this interchange of information, or discouraged the practice of some American companies of allowing their British associates to exploit in Britain and elsewhere the techniques which they have developed, would have serious repercussions on the British economy. It is to be hoped that this wider issue will be more fully and objectively discussed in the subsequent proceedings in Parliament.

\title{
TECHNICAL STUDENTS IN BRITAIN
}

TN speaking at a residential course for teachers in schools and technical colleges at St. Annes-on. Sea on January 21, Mr. A. A. Part, Under-Secretary in charge of the Further Education Branch at the Ministry of Education, said that the Minister had asked the Central Advisory Council for Education to make a special inquiry into the wastage of students in some of the main part-time courses in technical colleges. The inquiry was needed to provide more evidence from which the facts could be studied and, after referring to figures recently quoted by Lady Gertrude Williams and Dr. G. B. Frisby, director of the National Institute of Industrial Psychology, Mr. Part said that even without a special inquiry it could be seen that more practicable courses like the new course in mechanical engineering craft practice were required. It was also necessary to re-emphasize the relatively high standard of the National Certificate, and that this, even in its first three years up to Ordinary National Certificate, was designed for future technicians and technologists and was suitable only for those craft apprentices with an academic background above average and who showed strong promise of being able to rise out of the ranks of craftsmen. The really substantial wastage occurred at the beginning of the course, and available evidence suggested that very few of those who failed at the end of the first year of the course ultimately obtained an Ordinary National Certificate. Mr. Part believed that too many students were being admitted either with inadequate ability in mathematics or with too narrow an academic background, or both.

Mr. Part said that the weakness of many of the present arrangements lay in the inadequate standards of entry required by some colleges; the rigidity of some apprenticeship schemes, or their inflexible local interpretation; the often unsuccessful interpolation of several terms at an evening institute between leaving school and starting a National Certificate course ; and the temptation to some schools to narrow studies in the last year so as to concentrate on the three subjects normally required for the examination 
at the end of a "pre-S.1 course": mathematics, science and technical drawing. The main answer seemed to lie in the establishment by the colleges of standards of entry high and broad enough to ensure a much greater chance of success than is usual at present. These standards should apply to all National Certificate aspirants.

Summing up, Mr. Part visualized openings for some 3,500-4,000 sandwich course students a year from sixth forms, provided they had the necessary advanced-level qualifications. Those who had four appropriate passes at ordinary level of General Certificate of Education were eligible to enter directly into the second year of the National Certificate course and could thereby get their Ordinary National Certificate by, say, $18 \frac{1}{2}$ and then go either to the university by winning a Technical State Scholarship or to any of the advanced technical college courses. For those who stopped short of the General Certificate of Education or took a different route there was a whole variety of courses.

\section{MANAGEMENT OF SMALL FIRMS}

$\mathrm{T}$ $\mathrm{HE}$ difficulties of providing efficient management control in small engineering firms have been analysed by L. Fontaine, J. W. Walker and W. R. Spencer, of Urwick, Orr and Partners; they also make suggestions for introducing and using effective controls*.

In their paper the authors emphasize that, since nearly half of British industrial activity derives from small businesses, it is essential to our economic wellbeing that they should be well managed. If the manager is the only executive with real management ability, then he is forced to take responsibility for all sides of the business. His company is virtually a 'one-man-band' and its activities are limited to what he can personally achieve in his waking hours each day.

It is a truism that a business cannot stay still ; it must either grow larger or smaller. To meet the pressing problems of growth the manager is compelled to bring in (or promote) individuals who are capable of taking over the full responsibility for specific sides of the business. This action immediately causes new organizational problems, and the manager has to readjust his thinking and re-orientate his ideas of how he should run his business. The core of his problem is to build up a management team and to manage his business through them. His task is to set the objectives and to keep watch over the attainment (or otherwise) of these objectives by his sub-

* Management Control of Small Engineering Firms. Pp. 39. (Lon don: Institution of Mechanical Engineers, 1958.) 2s. $6 \dot{d}$. ordinates. To many managers of small businesses this can be a most difficult discipline; it is so much easier to continue to do things oneself than to learn how to ensure that others do them instead.

Although management control techniques are no substitute for dynamic leadership, they are, nevertheless, an inescapable part of the mechanisms of modern management. The principles governing these techniques have been tested and proved over and over again. The wise manager of the small business to-day will obtain a clear understanding of these principles before he applies them to specific problems; he will not import 'systems' as such, for they are unlikely to fit and will therefore fail.

The management control techniques considered by the authors are: first, the personal problems arising from the need to delegate responsibility to assistants ; secondly, the problems of how to control the design and manufacturing activities; and thirdly, the control of finance and costs and methods of ensuring profitability.

These three separate sets of management control techniques are closely interlinked and each technique is an essential piece in the whole management control pattern. It is possible to introduce isolated control techniques here and there, but the manager who is determined to set his growing business on a continuously successful course will not rest content until he has introduced adequate control over all sides of his business.

\section{THE COMMONWEALTH FUND}

$\mathrm{T}$ HE thirty-ninth annual report of the Common. wealth Fund (pp. xii +41 . New York: The Commonwealth Fund, 1957) covers the year ended June 30, 1957, in which 54 grants were voted totalling $3,808,913$ dollars, more than 90 per cent being towards the general area of health. The section dealing with medical education and community hoalth, for which 23 grants, totalling $2,009,346$ dollars, were voted, of which 11 were new, discusses the close relation and interdependence between social institutions responsible for training health personnel and those institutions and agencies through which health services are made available to the community. Following a review of the Fund's activities by the president, Mr. M. P. Aldrich, the Board decided that for the next fow years major emphasis in the health field should remain on medical education ; and its interest in community health, in medical research, in nursing and medical fellowships and awards, in related publications and in the programme of international fellowships should continue.
Cornell University received a grant for extending research on care of patients in the Comprehensive Care and Teaching Programme, which embraces both the traditional modical setting and the community and family setting. It should indicate the extent to which, and the manner in which, the application of medical skills is influenced by differing factors in the two environments. The University of Virginia School of Medicine is extending its pilot study of the diagnostic or general clinic as it affects the reorganization of tho out-patient department, and the University of Washington School of Nursing received a grant to complete a study of nursing education. Tulane University School of Medicine is studying the personality, emotional and motivational problems of medical students, and a study at the University of Chicago and at Loyola University, Chicago, is designed to develop tests for determining skill in clinical observation, in medical diagnosis and in dealing with professional situations. Grants were also made to the Faculty of Medicine at McGill 